\title{
FORMULASI DAN PENINGKATAN SIFAT KELARUTAN MINUMAN SERBUK COKELAT
}

\section{[Formulation and Improvement of Solubility Properties of Chocolate Beverage Pouder]}

\author{
Yulianto Hartono ${ }^{1)}$, Sugiyono ${ }^{2,3)}$, dan Nur Wulandari ${ }^{2,3)}$ \\ 1) Program Studi Magister Profesional Teknologi Pangan, Sekolah Pascasarjana, Institut Pertanian Bogor, Bogor \\ 2) Departemen Ilmu dan Teknologi Pangan, Fakultas Teknologi Pertanian, Institut Pertanian Bogor, Bogor \\ ${ }^{3)}$ Southeast Asian Food and Agricultural Science and Technology (SEAFAST) Center, Institut Pertanian Bogor, Bogor
}

Diterima 6 Februari 2018 / Disetujui 7 November 2018

\begin{abstract}
Chocolate beverage powder (CBP) consists of cocoa powder, sugar and milk powder and their compositons are important for consumer's acceptance. Generally, wettability due to the hydrophob icity of the cocoabutter is a problem and lecithination is often used to improve the wettability. Because CBP production process utilizes dry blending method, the incorporation of lecithin is a challenge. There of this stu$d y$, aimed to (1) formulate CBP produced by dry blending as well as to (2) improve its wettability using prepared soy (de-oiled) lecithin powder and soy liquid lecithin. A hedonic test using 50 respondents was carried out to obtain the preferred formula. Two methods of lecithin addition were tested (i) premixing with cocoa powder and (ii) direct addition during dry blending process. Liquid lecithin was added by spraying at $70^{\circ} \mathrm{C}$ to the material during dry blending. The amount of prepared lecithin added were $0.5,2.0$, and $4.0 \%$ for lecithin powder and 0.5, 1.0, 2.0, 2.5, and 3.0\% for liquid lecithin. The results showed that the formula with the highest overall like (6.7) was that containing $40 \%$ instant whole milk powder, $40 \%$ sugar castor, $10 \%$ alkalized cocoa powder, $9.7 \%$ maltodextrin and $0.3 \%$ salt. It was clearly showed that liquid lecithin was more effective in improving wettability as compared to lecithin powder and there was no significant differences between premixing and direct addition method. The amount of prepared liquid lecithin needed to meet the wettability target of below 30 seconds the selected formula without giving significant difference in taste was $25 \%$.
\end{abstract}

Keywords: chocolate beverage powder, dry blending, formulation, solubility properties, soy lecithin

\begin{abstract}
ABSTRAK
Minuman serbuk cokelat terdiri dari bubuk cokelat, gula dan susu bubuk yang kombinasinya penting bagi penerimaan konsumen. Wettability menjadi masalah untuk produk ini yang disebabkan oleh sifat hidrofobik cocoa butter pada bubuk cokelat. Lesitinisasi sering digunakan untuk meningkatkan wettability. Pada proses pencampuran kering, penambahan lesitin ke dalam bahan lainnya memiliki keterbatasan secara teknis. Penelitian ini bertujuan untuk (1) memformulasikan minuman serbuk cokelat diproses dengan pencampuran kering dan juga (2) meningkatkan wettability-nya menggunakan sediaan lesitin kedelai bubuk bebas minyak (de-oiled) dan cair. Uji hedonik dilakukan untuk mendapatkan formula yang disukai menggunakan 50 responden. Dua metode aplikasi penambahan sediaan lesitin diujikan terhadap formula terpilih, yaitu dengan membuat premiks bersama bubuk cokelat dan dengan menambahkan langsung saat pencampuran kering. Sediaan lesitin cair ditambahkan dengan cara menyemprotkan ke bahan pada suhu $70^{\circ} \mathrm{C}$ saat pencam puran kering. Jumlah sediaan lesitin bervariasi dari 0,$5 ; 2,0$; dan $4,0 \%$ untuk lesitin bubuk dan dari 0,$5 ; 1,0 ; 2,0 ; 2,5$; dan $3,0 \%$ untuk lesitin cair. Hasil pengujian menunjukkan formula dengan tingkat kesukaan tertinggi $(6,7)$ memiliki komposisi $40 \%$ susu bubuk lemak utuh instan, $40 \%$ gula kastor, $10 \%$ bubuk cokelat teralkalisasi, 9,7\% maltodekstrin, dan 0,3\% garam. Lesitin cair lebih efektif dibandingkan lesitin bubuk, dan tidak ada perbedaan signifikan hasil wettability antara perlakuan penambahan lesitin premiks maupun langsung. Jumlah sediaan lesitin cair yang diperlukan untuk mencapai target wettability di bawah 30 detik untuk formula terpilih adalah 2,5\% tanpa memberikan perbedaan rasa yang signifikan.
\end{abstract}

Kata kunci: formulasi, lesitin kedelai, minuman serbuk cokelat, pencampuran kering, sifat kelarutan

\footnotetext{
*Penulis Korespondensi:

E-mail: ssugiyono@yahoo.com.au
} 


\section{PENDAHULUAN}

Minuman serbuk cokelat dalam bentuk bubuk memiliki keunggulan masa simpan yang panjang dibandingkan bentuk cair karena kadar air dan aktivitas air $\left(a_{w}\right)$ yang rendah sehingga membatasi pertumbuhan mikroba dan juga reaksi kimia yang dapat menurunkan kualitas (ljabadeniyi dan Pillay, 2017). Kemudahan dalam pelarutan dalam air menjadi faktor penting bagi konsumen dan menentukan persepsi terhadap kualitas menyeluruh dari produk tersebut (Fang et al., 2008).

Minuman serbuk cokelat umumnya dibuat dari bahan utama bubuk cokelat (cocoa powder), susu bubuk, dan gula yang juga bisa ditambahkan sedikit pengemulsi dan perisa (Aliakbarian et al., 2017) ataupun dengan penambahan sedikit hidrokoloid untuk mencegah sedimen cokelat setelah dilarutkan sebagai bahan tambahan pangan (Eduardo et al., 2014). Kombinasi dari ketiga bahan utama ini penting dalam menentukan penerimaan konsumen karena memengaruhi rasa dan warna dari produk (Dogan et al., 2016). Menurut Paixao et al. 2014, konsentrasi ideal bubuk cokelat berada di antara 10 dan $25 \mathrm{~g} / 160 \mathrm{~mL}$ sedangkan untuk konsentrasi sukrosa ideal adalah $7,0 \%$ (b/b) untuk suhu konsumsi $6^{\circ} \mathrm{C}$ dan $5,2 \%(\mathrm{~b} / \mathrm{b})$ untuk suhu konsumsi pada $45^{\circ} \mathrm{C}$. Produk ini memiliki karakteristik dasar kandungan kakao tidak kurang dari 10\% (berat kering) sesuai kategori pangan BPOM 5.1.1. Kandungan bubuk cokelat antara $5-20 \%$ dalam formulasi membuat produk menjadi sulit untuk dilarutkan dalam air, namun ini merupakan faktor utama untuk mendapatkan rasa cokelat dan warna yang pas (Vissotto et al., 2010).

Proses pelarutan bubuk diawali dengan pembasahan permukaan bubuk oleh air yang dikenal dengan istilah wettability. Secara umum ada empat fase pada proses ini yaitu: proses pembasahan (wetting), tenggelam (submerging), terdispersi (dispersing), dan pelarutan (dissolving) (Forny et al., 2011). Proses ini terjadi secara berurutan sehingga proses pembasahan sering menjadi langkah penentu dari kecepatan pelarutan (Dhanalakshmi et al., 2011). Pada bubuk yang memiliki hambatan pada tahap pembasahan, proses granulasi yang memperbesar ukuran partikel dapat dipertimbangkan sebagai solusi khususnya jika sifat permukaan bubuk tidak termodifikasi pada proses pengeringan semprot (Richard et al., 2013). Bubuk yang terdispersi dalam air hangat maupun dingin dengan pengadukan yang minim tanpa terbentuknya gumpalan dan sedimen tidak terlarut dikenal sebagai bubuk instan (Fang et al., 2008).

Bubuk cokelat secara alami memiliki wettability yang buruk karena kandungan cocoa butter yang bersifat hidrofobik (Vissotto et al., 2010). Fitzpatrick et al. (2017) menyebutkan bahwa bubuk cokelat de- ngan kadar lemak 5,9\% membutuhkan waktu pembasahan lebih dari 1 jam pada suhu $20^{\circ} \mathrm{C}$. Penambahan gula khususnya yang memiliki ukuran partikel yang besar, membantu proses rehidrasi bubuk cokelat (Abdelaziz et al., 2014). Wettability dinilai baik jika terjadi dalam waktu kurang dari 30 detik (Bylund, 1995).

Teknik yang banyak dilakukan untuk memperbaiki wettability pada industri susu adalah dengan penyemprotan lesitin dalam bentuk cair pada bubuk yang hampir kering di secondary fluidized bed sehingga lesitin menyelimuti permukaan bubuk (Lallbeeharry et al., 2014). Teknik lain yang digunakan adalah dengan mencampurkan lesitin dengan susu lemak utuh sebelum proses pengeringan semprot (spray drying) untuk membuat susu bubuk lemak utuh instan (Tian et al., 2014). Metode ini banyak dilakukan pada produk yang diproduksi melalui proses pengeringan semprot dan bukan pencampuran kering (dry blending). Proses pengeringan semprot merupakan proses yang kompleks, membutuhkan investasi tinggi, dan membutuhkan energi yang besar dibandingkan dengan proses pencampuran kering (Kent et al., 2015). Parameter proses peningkatan wettability dengan lesitinisasi pada proses pencampuran kering belum banyak diketahui.

Penelitian ini bertujuan mendapatkan formulasi yang disukai oleh konsumen dan mencari solusi yang efektif untuk meningkatkan wettability dari minuman serbuk cokelat yang diproduksi dengan pencampuran kering. Hasil dari penelitian ini dapat memberikan acuan dan referensi dalam pengembangan produk minuman serbuk cokelat yang diproduksi dengan pencampuran kering khususnya dalam hal formulasi. Manfaat lain adalah memberikan solusi yang efektif bagi industri untuk memperbaiki wettability produknya dengan memperhatikan juga aspek biaya.

\section{BAHAN DAN METODE}

\section{Bahan}

Bahan utama yang digunakan pada penelitian ini adalah bubuk cokelat teralkalisasi DF 740-11 (Barry Callebout, Malaysia), susu bubuk lemak utuh instan (Fonterra, New Zealand), garam halus refina JS-100 (PT. UNICHEM, Indonesia), sediaan lesitin kedelai bubuk (de-oiled lecithin) SOLEC FS B dengan kandungan fosfolipid sebagai bahan aktif sebesar minimum 97\%, sediaan lesitin kedelai cair SOLEC MB 45 dengan kandungan fosfolipid sebesar minimum 30\% (Solae Europe, Netherlands).

\section{Formulasi untuk mendapatkan formula dasar mi- numan serbuk cokelat}

Pre-seleksi formulasi pencampuran kering dilakukan dengan bahan dasar dan variabel dosis yaitu 
susu bubuk lemak utuh instan (30, 35, dan 40\%), bubuk cokelat $(10,15$, dan $20 \%)$, gula kastor (25, 30, dan 40\%) (PT Andalan Furnindo, Indonesia), garam $(0,3 \%)$ dan maltodekstrin 01915 (Cargill, China) sebagai bahan pengisi (mengisi hingga 100\%). Dari variabel ini didapatkan 27 formula (Tabel 1) yang dilakukan pre-seleksi dengan Focus Group Discussion (FGD) oleh 4 panelis terlatih untuk mengelompokkan formula tersebut berdasarkan kemiripan rasa sehingga didapatkan 7 formula yang mewakili tiap-tiap kelompok. Ketujuh formula ini kemudian diuji hedonik skala 1-9 (kriteria 1: amat sangat tidak suka, 2: sangat tidak suka, 3: tidak suka, 4: agak tidak suka, 5: biasa saja (netral), 6: agak suka, 7: suka, 8: sangat suka, 9: amat sangat suka) untuk mengetahui tingkat penerimaannya oleh 50 panelis tidak terlatih yang merupakan representasi dari konsumen minuman cokelat yang berada di area Jabodetabek. Berdasarkan Ackbarali dan Maharaj (2014), minimum dibutuhkan 20 panelis untuk uji hedonik skala pilot. Responden juga dimintai komentar dan purchase intent terhadap produk. Produk dilarutkan $40 \mathrm{~g}$ dalam $180 \mathrm{~mL}$ air dengan suhu $50 \pm 1^{\circ} \mathrm{C}$ dan disajikan dalam kondisi hangat $40 \pm 1^{\circ} \mathrm{C}$. Kemudian data diolah menggunakan FIZZ sensory analysis software (Biosystemes, Perancis) dengan Tukey test $5 \%$ untuk mengetahui signifikansi hasil overall liking dari masing-masing formula. Formula yang dipilih adalah yang memiliki skor tertinggi dengan juga mempertimbangkan aspek biaya.

\section{Peningkatan wettability formula terpilih menggu- nakan lesitin kedelai}

Dua tipe lesitin digunakan dalam tahap ini yaitu lesitin bubuk bebas minyak dan lesitin cair. Pencampuran lesitin bubuk dilakukan dengan dua metode yaitu (1) lesitin bubuk dibuat premiks dengan bubuk cokelat yang kemudian dicampurkan dengan bahan lain pada saat pencampuran kering; dan (2) lesitin bubuk dicampurkan langsung pada saat pencampur- an kering. Jumlah sediaan lesitin bubuk yang digunakan adalah 0,$5 ; 2,0$; dan $4,0 \%$ untuk kedua cara. Aplikasi lesitin cair dilakukan melalui penyemprotan menggunakan spray gun (garden pump and spray 1,0 liter Kris Garden) untuk menghasilkan kabut pada suhu $70^{\circ} \mathrm{C}$ dengan 2 cara, yaitu (1) lesitin disemprotkan pada bubuk cokelat (premiks), kemudian dicampurkan dengan bahan lain, dengan jumlah sediaan 0,5 dan $1,0 \%$, dan (2) lesitin disemprotkan langsung pada saat pencampuran kering dengan jumlah sediaan 0,$5 ; 1,0 ; 2,0 ; 2,5$; dan $3,0 \%$. Pada penggunaan lesitin cair terdapat keterbatasan karena pada jumlah sediaan tinggi $(2,0 \%$ untuk metode premiks dan 3,0\% untuk metode langsung) membuat produk menjadi lengket. Proses pencampuran kering dilakukan dalam skala laboratorium menggunakan powder dry horizontal mixer mini lindor L00010-R-CR00000 (Lindor Machinefabrieken B.V, The Netherlands) dengan kecepatan 12 rpm dan waktu pencampuran 5 menit.

Pemilihan formula berdasarkan wettability yang memenuhi target di bawah 30 detik, dengan juga mempertimbangkan aspek biaya. Produk akhir terpilih kemudian diuji tetrad terhadap produk kontrol untuk melihat signifikansi perbedaannya secara sensori. Pada uji ini 10 panelis terlatih diminta mengelompokkan 4 sampel menjadi 2 pasang dimana tiap pasang memiliki sensori yang identik (Ennis dan Jesionka, 2011). Setiap panelis melakukan evaluasi dalam 2 repetisi. Minimum jawaban benar yang menunjukkan signifikansi pada level kepercayaan 95\% adalah 11 .

\section{Analisis distribusi ukuran partikel (Laser Diffrac- tion, Coulter)}

Ukuran partikel rata-rata berdasarkan volume bola (mean particle size, $D_{4,3}$ ) diukur dengan laser diffraction particle size analyzer LS 13320 (Beckman Coulter, USA).

Tabel 1. Formula pra-seleksi minuman serbuk cokelat dengan variabel dosis bahan dasar susu bubuk, bubuk cokelat dan gula.

\begin{tabular}{|c|c|c|c|c|c|c|c|c|c|c|c|c|c|c|}
\hline \multirow{2}{*}{ Material } & \multicolumn{14}{|c|}{$\%$ Berat } \\
\hline & P1 & $\mathrm{P} 2$ & P3 & P4 & P5 & P6 & P7 & P8 & P9 & $\mathrm{P} 10$ & $\mathrm{P} 11$ & $\mathrm{P} 12$ & $\mathrm{P} 13$ & $\overline{\mathrm{P} 14}$ \\
\hline Susu bubuk & 30 & 30 & 30 & 30 & 30 & 30 & 30 & 30 & 30 & 35 & 35 & 35 & 35 & 35 \\
\hline Bubuk cokelat & 10 & 10 & 10 & 15 & 15 & 15 & 20 & 20 & 20 & 10 & 10 & 10 & 15 & 15 \\
\hline Gula & 25 & 30 & 40 & 25 & 30 & 40 & 25 & 30 & 40 & 25 & 30 & 40 & 25 & 30 \\
\hline Garam & 0,3 & 0,3 & 0,3 & 0,3 & 0,3 & 0,3 & 0,3 & 0,3 & 0,3 & 0,3 & 0,3 & 0,3 & 0,3 & 0,3 \\
\hline Maltodekstrin & 34,7 & 29,7 & 19,7 & 29,7 & 24,7 & 14,7 & 24,7 & 19,7 & 9,7 & 29,7 & 24,7 & 14,7 & 24,7 & 19,7 \\
\hline Total & 100 & 100 & 100 & 100 & 100 & 100 & 100 & 100 & 100 & 100 & 100 & 100 & 100 & 100 \\
\hline \multirow{2}{*}{ Material } & \multicolumn{14}{|c|}{$\%$ Berat } \\
\hline & P15 & P16 & P17 & P18 & P19 & P20 & P21 & P22 & P23 & P24 & P25 & P26 & P27 & \\
\hline Susububuk & 35 & 35 & 35 & 35 & 40 & 40 & 40 & 40 & 40 & 40 & 40 & 40 & 40 & \\
\hline Bubuk cokelat & 15 & 20 & 20 & 20 & 10 & 10 & 10 & 15 & 15 & 15 & 20 & 20 & 20 & \\
\hline Gula & 40 & 25 & 30 & 40 & 25 & 30 & 40 & 25 & 30 & 40 & 25 & 30 & 39,7 & \\
\hline Garam & 0,3 & 0,3 & 0,3 & 0,3 & 0,3 & 0,3 & 0,3 & 0,3 & 0,3 & 0,3 & 0,3 & 0,3 & 0,3 & \\
\hline Maltodekstrin & 9,7 & 19,7 & 14,7 & 4,7 & 24,7 & 19,7 & 9,7 & 19,7 & 14,7 & 4,7 & 14,7 & 9,7 & 0 & \\
\hline Total & 100 & 100 & 100 & 100 & 100 & 100 & 100 & 100 & 100 & 100 & 100 & 100 & 100 & \\
\hline
\end{tabular}


Instrumen ini menggunakan $5 \mathrm{~mW}$ laser diode dengan panjang gelombang $750 \mathrm{~nm}$ sebagai sumber cahaya dan lampu tungsten-halogen sebagai sumber cahaya sekunder untuk sistem PIDS (Polarization Intensity Differential Scattering). Sampel bubuk disiapkan dalam gelas ukur yang disiapkan hingga tanda batas kemudian dimasukkan ke dalam Tornado Dry Powder System yang terhubung dengan vakum $420 \mathrm{~L} /$ menit pada $740-750$ torr $(15 \mathrm{cfm}$ pada 5-10 inci air di bawah tekanan atmosferik). Analisis triplo dilakukan untuk tiap-tiap sampel.

\section{Analisis densitas kamba atau bulk density (IDF, 2005b)}

Sampel ditimbang 100,0 $\pm 0,1 \mathrm{~g}$ dan dimasukkan ke dalam gelas ukur 250 mL. Gelas ukur diletakkan dalam alat Stampvolumeter STAV 2003 JEL (Funke Gerber, Germany) dan diketuk (tapping) sebanyak 625 kali. Densitas kamba dihitung dengan membagi berat sampel dengan volume setelah pengetukan.

\section{Analisis dispersibility (IDF, 2013)}

Analisis ini mencakup partikel terapung dan SDP. Sampel bubuk sebanyak $14,40 \pm 0,05 \mathrm{~g}$ ditambahkan dalam $100 \mathrm{~g}( \pm 1 \mathrm{~g})$ air demineral $25 \pm 1^{\circ} \mathrm{C}$. Setelah 5 detik sampel diaduk sebagai berikut: 6 putaran searah jarum jam, 6 putaran berlawanan jarum jam, 6 putaran searah jarum jam, dan 6 putaran berlawanan arah jarum jam. Total waktu pengadukan 10 detik. Larutan sampel dibiarkan selama 2 menit. Kemudian partikel yang mengambang (partikel terapung) diamati pada permukaan larutan dengan kriteria sebagai berikut: tidak ada (-): 0-3 partike kecil, beberapa (+): 4-10 partikel kecil, banyak (++): lebih dari 10 partikel. Larutan diaduk kembali 1 putaran dan dituang perlahan ke dalam cawan petri. Cawan petri ditiriskan dalam posisi terbalik dan ditunggu selama 2 menit. Setelah 2 menit hasilnya diamati dan dibandingkan dengan standar referensi SDP. Kategori untuk SDP : A (sangat baik); B (baik); C (sedang); D (dapat diterima); E (tidak dapat diterima).

\section{Analisis insolubility index (IDF, 2005a)}

Sampel bubuk sebanyak $13 \mathrm{~g}$ dan $100 \mathrm{~mL}$ air destilata suhu kamar dicampur menggunakan Solumixer (Gerber Instruments, USA). Pencampuran dilakukan selama 90 detik dengan kecepatan 3800$4000 \mathrm{rpm}$. Sampel sebanyak $50 \mathrm{~mL}$ di sentrifugasi (Super Vario-N 3680-2378 (Funke Gerber, USA)) selama 5 menit pada kecepatan 900 rpm kemudian banyaknya endapan dicatat.

\section{Analisis wettability (IDF, 2013)}

Akuades $250 \mathrm{~mL}\left(25 \pm 1^{\circ} \mathrm{C}\right)$ disiapkan dalam gelas piala $600 \mathrm{~mL} 10 \mathrm{~g}( \pm 0,05 \mathrm{~g})$ sampel ditimbang dan dituang ke dalam tabung yang berada tepat di atas gelas piala dan diratakan di atas pelat dengan spatula. Pelat ditarik dan secara bersamaan stopwatch diaktifkan. Stopwatch dimatikan ketika semua partikel sampel sudah tenggelam dan waktunya dicatat.

\section{Analisis data}

Pengolahan dan analisis data hasil penelitian dilakukan dengan melihat hubungan perlakuan dan jumlah sediaan lesitin terhadap parameter-parameter yang diuji. Data yang diperoleh disajikan dalam grafik korelasi rata-rata atribut terhadap jumlah sediaan lesitin dan tipe perlakuan dilengkapi standard error bar menggunakan Microsoft Excel 2010 dan diolah hasilnya secara statistik menggunakan ANOVA (uji Dunnet dengan level kepercayaan 95\%) untuk melihat signifikansi dibandingkan kontrol menggunakan SPSS 23.

\section{HASIL DAN PEMBAHASAN}

\section{Formula dasar minuman serbuk cokelat}

Berdasarkan hasil FGD, 27 formula yang diujikan dapat dikelompokkan menjadi 7 grup berdasarkan rasa dan 1 formula dipilih mewakili tiap grup tersebut (P6, P9, P10, P15, P16, P18 dan P21) untuk dilanjutkan ke uji hedonik menggunakan 50 responden yang kemudian akan dihasilkan 1 formula terpilih berdasarkan hasil overall liking dan pertimbangan biaya formula.

Profil 50 responden pada uji hedonik mayoritas adalah perempuan (76\%), berumur 25-35 tahun $(40 \%)$, tinggal di Jakarta (68\%), sering mengonsumsi minuman susu UHT cokelat (82\%), merek yang sering digunakan adalah merek $X(64 \%)$, mengonsumsi produk 3 kali seminggu (32\%), dan mengonsumsi produk dalam kondisi dingin (82\%). Hasil nilai overall liking seperti yang ditampilkan pada Tabel 2, menunjukkan P21 memilki nilai tertinggi $(6,7)$ signifikan berbeda dibandingkan prototipe lain kecuali dengan P15 (Tukey test dengan level kepercayaan 95\%). Namun mempertimbangkan dari segi biaya formula maka P21 menjadi formula terpilih untuk selanjutnya ditingkatkan wettability-nya.

Alasan P15 dan P21 memiliki overall liking yang tinggi dibandingkan prototipe lainnya dapat diketahui dari komentar responden. Rasa cokelat yang pas didominasi oleh P15 dan P21 (dengan kandungan bubuk cokelat berturut-turut 15 dan 10\%) sesuai dengan komentar dari 6 responden. Rasa yang seimbang dan manis yang pas dimiliki oleh P21 (kandungan gula dan susu bubuk masing-masing 40\%) sesuai komentar dari 10 responden. Kedua hal ini menjadi faktor positif yang juga mendorong purchase intent dari produk. 
Tabel 2. Nilai rata-rata overall liking, purchase intent dan biaya formula minuman serbuk cokelat

\begin{tabular}{lccccccc}
\hline & \multicolumn{9}{c}{ Prototipe } \\
\cline { 2 - 8 } & $\mathrm{P} 6$ & $\mathrm{P} 9$ & $\mathrm{P} 10$ & $\mathrm{P} 15$ & $\mathrm{P} 16$ & $\mathrm{P} 18$ & $\mathrm{P} 21$ \\
\hline Overall liking $^{*}$ & $5,36 \pm 1,70$ & $5,42 \pm 1,83$ & $5,50 \pm 1,78$ & $6,24 \pm 1,48$ & $4,62 \pm 2,01$ & $5,60 \pm 2,13$ & $6,74 \pm 1,2$ \\
Purchase intent $(\%)$ & $\mathrm{CD}$ & $\mathrm{BCD}$ & $\mathrm{BC}$ & $\mathrm{AB}$ & $\mathrm{D}$ & $\mathrm{BC}$ & $4 \mathrm{~A}$ \\
Biaya formula (Rp/kg) & 36,0 & 32,0 & 36,0 & 56,0 & 18,0 & 38,0 & 64,0 \\
\hline
\end{tabular}

Keterangan: *Huruf yang sama tidak menunjukkan perbedaan yang signifikan (Tukey test, level kepercayaan 95\%). Hasil nilai rerata overall liking dari 50 responden

\section{Wettability formula terpilih}

Formula terpilin P21 ditingkatkan wettability-nya menggunakan lesitin kedelai bubuk dan cair dengan perlakuan penambahan lesitin melalui metode premiks dan metode langsung, serta jumlah sediaan sebagai variabel. Parameter yang diuji adalah ukuran partikel, densitas kamba, partikel terapung, SDP, insolubility index dan wettability. Perlakuan yang memberikan wettability sesuai target di bawah 30 detik dipilih dengan mempertimbangkan biaya formula.

\section{Ukuran partikel}

Penambahan lesitin bubuk dengan metode premiks hingga jumlah sediaan $4 \%$ tidak merubah ukuran rata-rata partikel dari produk. Namun perlakuan metode langsung mulai jumlah sediaan $1 \%$ signifikan (Dunnet, $P<0,05)$ membuat ukuran partikel menjadi lebih besar tetapi seiring meingkatnya jumlah sediaan tidak terjadi peningkatan ukuran. Metode premiks dengan dua kali pencampuran menyebabkan partikel halus (dusty powder) banyak tertinggal pada Lindor mixer sehingga mengompensasi ukuran partikel dari lesitin bubuk yang besar (granul; ukuran rata-rata partikel 154,6 $\mu \mathrm{m}$ ) menggantikan maltodekstrin (bahan pengisi) yang berupa bubuk halus berukuran kecil (ukuran rata-rata partikel 129,0 um). Penambahan lesitin cair metode langsung signifikan meningkatkan ukuran partikel pada jumlah sediaan 2,5 dan $3,0 \%$ (Dunnet, $P<0,05$ ) seperti yang ditampilkan pada Gambar 1. Hal ini disebabkan penambahan lesitin cair metode langsung jumlah sediaan 2,5 dan 3,0\% mereduksi partikel kecil berukuran 4-40 $\mu \mathrm{m}$ seperti yang ditunjukkan pada Gambar 2. Semakin tinggi konsentrasi lesitin cair melapisi permukaan maka semakin tebal lapisan yang terbentuk (Ji et al., 2017). Hal ini juga sejalan dengan hasil penelitian $\mathrm{Ji}$ et al. (2017), bahwa terjadi peningkatan ukuran partikel $\left(D_{50}\right)$ bubuk Isolat Protein Whey yang dilapisi dengan lesitin seiring dengan bertambahnya dosis dari $54,5 \mu \mathrm{m}$ (standar; dosis $0 \%$ ) menjadi $114,4 \mu \mathrm{m}$ (dosis $5 \%$ ). Ukuran partikel erat kaitannya dengan wettability, karena mempengaruhi volume partikel dan porositas/kapilaritas. Berdasarkan penelitian Selomulya dan Fang (2013), ukuran partikel $<100 \mu \mathrm{m}$ cukup membuat produk sulit terbasahi dan tenggelam dalam air. Menurut
Fitzpatrick et al. (2016), partikel yang berukuran kecil membuat air sulit berpenetrasi ke dalam bubuk.

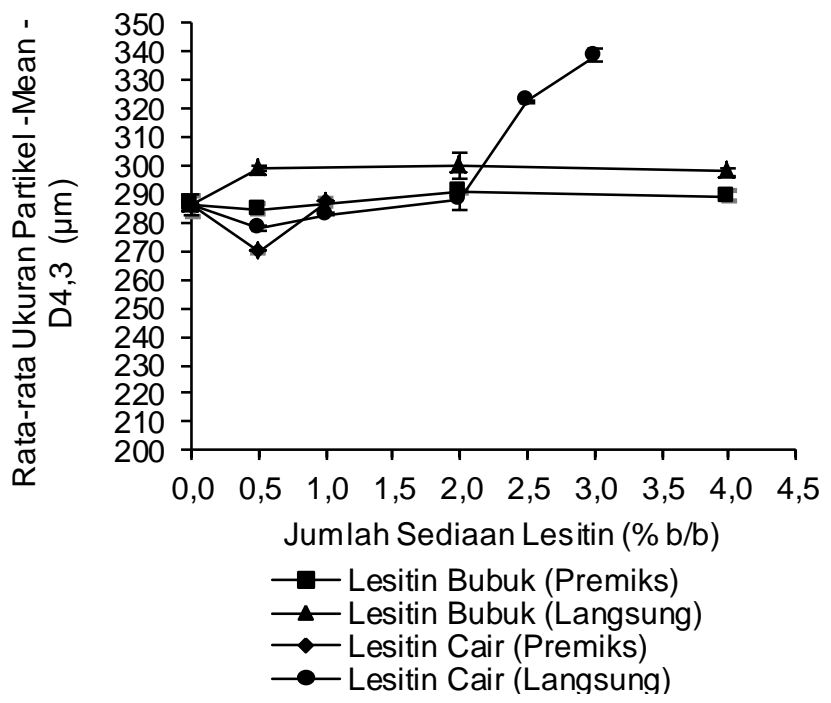

Gambar 1. Ukuran rata-rata partikel minuman serbuk cokelat menggunakan lesitin bubuk dan lesitin cair

\section{Densitas kamba}

Penambahan lesitin bubuk signifikan memengaruhi densitas kamba yang lebih rendah pada jumlah sediaan $4,0 \%$ sedangkan untuk lesitin cair mulai pada jumlah sediaan $1,0 \%$ (Dunnet, $P<0,05$ ) seperti yang ditampilkan pada Gambar 3 .

$\mathrm{Hal}$ ini disebabkan lesitin mengandung lebih dari $90 \%$ lemak yang memiliki densitas lebih rendah (densitas kamba lesitin bubuk $0,45 \mathrm{~g} / \mathrm{mL}$ ) seperti yang dikemukakan Dogan et al. (2016). Pada penambahan lesitin cair, peningkatan ukuran partikel juga berkontribusi pada turunnya densitas kamba yang pada akhirnya menjadi faktor fisik dalam memberikan efek positif pada wettability.

\section{Partikel terapung}

Penambahan lesitin bubuk maupun cair seiring dengan meningkatnya jumlah sediaan dapat mengurangi partikel terapung seperti yang ditunjukkan pada Tabel 3. Ini sangat berkaitan erat dengan tingkat wettability dimana partikel yang tidak terbasahi sempurna dan membentuk gumpalan (kandungan lemak yang lengket pada permukaan memblokir efek kapiler) akan naik ke permukaan dan menyebabkan partikel terapung (Dupas et al., 2015). 


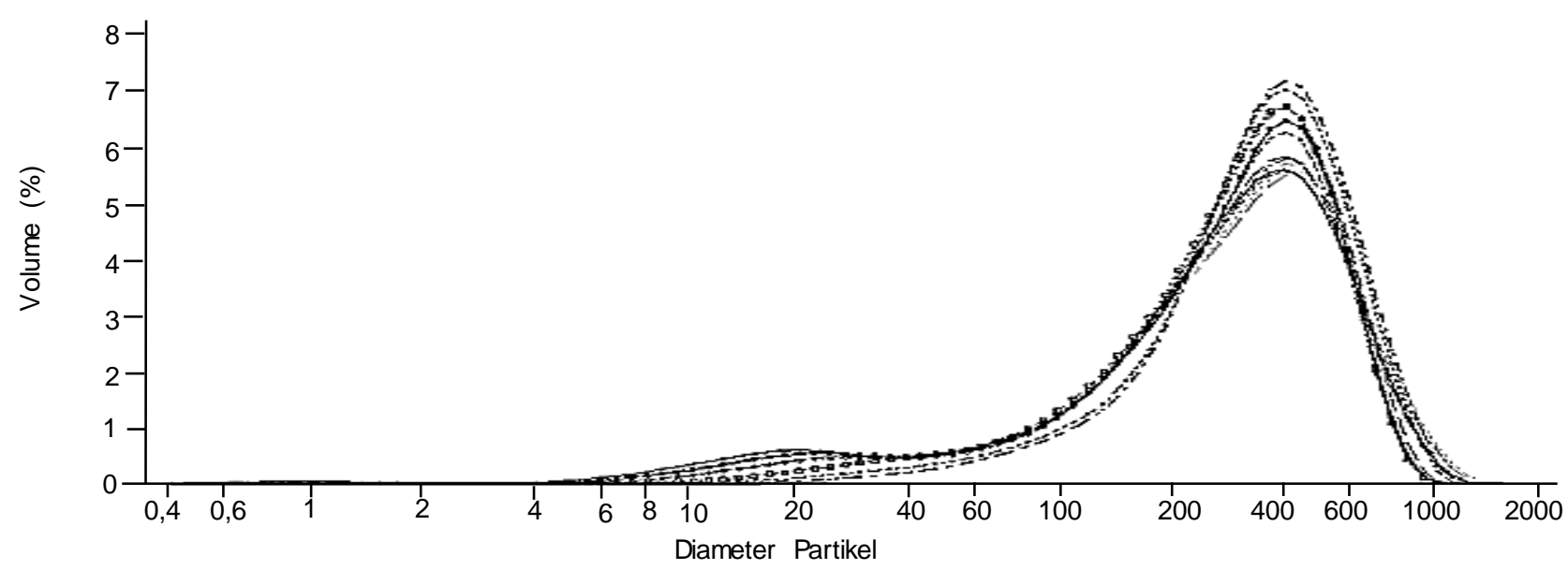

Gambar 2. Distribusi ukuran partikel minuman serbuk cokelat menggunakan lesitin bubuk dan lesitin cair

Lesitin bubuk maupun cair, membantu mengatasi hal ini karena memiliki gugus hidrofilik dan hidrofobik (efek surfaktan). Semakin baik wettability maka partikel terapung semakin berkurang

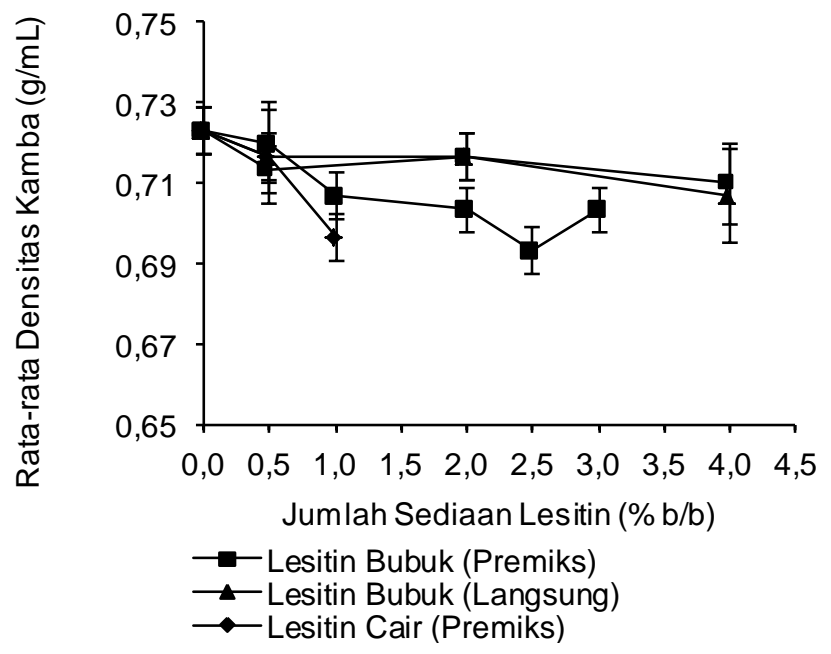

Gambar 3. Densitas kamba minuman serbuk cokelat menggunakan lesitin bubuk dan lesitin cair

Pada lesitin bubuk jumlah sediaan $4,0 \%$ dengan metode penambahan premiks dapat menghilangkan partikel terapung. Sedangkan untuk lesitin bubuk dengan penambahan langsung, mulai jumlah sediaan $0,5 \%$ partikel terapung sudah mulai berkurang dan menghilang pada jumlah sediaan 2,0\%. $\mathrm{Hal}$ ini menunjukkan bahwa lesitin bubuk dengan perlakuan penambahan langsung mempunyai efek yang lebih besar dalam mengurangi partikel terapung dibandingkan perlakuan premiks pada jumlah sediaan yang sama. Ini disebabkan dengan penambahan langsung lesitin bubuk dapat lebih merata tidak hanya dengan bubuk cokelat namun dengan keseluruhan bahan.

Tabel 3. Partikel terapung minuman serbuk cokelat menggunakan lesitin bubuk dan lesitin cair

\begin{tabular}{|c|c|c|c|c|}
\hline \multirow{2}{*}{$\begin{array}{c}\text { Jumlah } \\
\text { Sediaan } \\
\text { Lesitin } \\
(\%)\end{array}$} & \multicolumn{4}{|c|}{ Partikel Terapung Minuman Serbuk Cokelat } \\
\hline & $\begin{array}{c}\text { Lesitin } \\
\text { Bubuk } \\
\text { (Premiks) }\end{array}$ & $\begin{array}{c}\text { Lesitin } \\
\text { Bubuk } \\
\text { (Langsung) }\end{array}$ & $\begin{array}{c}\text { Lesitin } \\
\text { Cair } \\
\text { (Premiks) }\end{array}$ & $\begin{array}{l}\text { Lesitin Cair } \\
\text { (Langsung) }\end{array}$ \\
\hline 0 & ++ & ++ & ++ & ++ \\
\hline $\begin{array}{l}0,5 \\
1,0\end{array}$ & ++ & + & + & + \\
\hline 2,0 & ++ & - & & - \\
\hline 2,5 & & & & - \\
\hline 3,0 & & & & - \\
\hline 4,0 & - & - & & \\
\hline
\end{tabular}

Keterangan: Bagian tabel yang kosong, data tidak tersedia karena tidak dilakukan pengujian pada jumlah sediaan tersebut

Pada lesitin cair tidak terdapat perbedaan hasil partikel terapung antara perlakuan premiks dan langsung. Pada penambahan sediaan lesitin cair $0,5 \%$ partikel terapung berkurang dan menghilang pada penambahan sediaan lesitin cair $1,0 \%$ atau lebih. Hal ini disebabkan lesitin cair bekerja dengan menyelimuti permukaan partikel. Penambahan sediaan lesitin cair sebanyak $0,5 \%$ sudah cukup untuk menjangkau permukaan partikel khususnya bubuk cokelat pada perlakuan langsung seperti halnya pada perlakuan premiks. 


\section{Slowly dissolving particle (SDP)}

Produk minuman serbuk cokelat ini memiliki SDP E (tidak dapat diterima) mengingat pengujian dilakukan pada suhu $25^{\circ} \mathrm{C}$ dimana cocoa butter masih dalam bentuk padat. Berdasarkan Naik dan Kumar (2014), titik leleh dari cocoa butter adalah 35$37^{\circ} \mathrm{C}$. Penambahan lesitin bubuk maupun cair tidak memberikan perbaikan yang signifikan pada indeks SDP secara umum seperti yang ditampilkan pada Tabel 4. Hanya pada jumlah sediaan $2,0 \%$ untuk lesitin bubuk perlakuan premiks dan $0,5 \%$ dan $1,0 \%$ untuk lesitin cair perlakuan langsung yang memiliki SDP D (dapat diterima) dan pada jumlah sediaan lebih tinggi SDP kembali ke E. Hal ini disebabkan lesitin membantu interaksi dengan air karena bersifat sebagai surfaktan dan emulsifier alami namun lesitin sendiri tidak larut dalam air namun terdispersi (Pichot et al., 2013) sehingga pada jumlah sediaan tinggi juga dapat memperburuk hasil SDP. Dapat disimpulkan bahwa secara keseluruhan lesitin yang ditambahkan tidak banyak membantu dalam dispersibilitas produk di dalam air walaupun wettability-nya meningkat.

Tabel 4. SDP indeks minuman serbuk cokelat menggunakan lesitin bubuk dan lesitin cair

\begin{tabular}{|c|c|c|c|c|}
\hline \multirow{2}{*}{$\begin{array}{l}\text { Jumlah } \\
\text { Sediaan } \\
\text { Lesitin } \\
(\%)\end{array}$} & \multicolumn{4}{|c|}{$\begin{array}{c}\text { Slowly Dissolving Particle (SDP) Index Minuman } \\
\text { Serbuk Cokelat }\end{array}$} \\
\hline & $\begin{array}{c}\text { Lesitin } \\
\text { Bubuk } \\
\text { (Premiks) }\end{array}$ & $\begin{array}{c}\text { Lesitin } \\
\text { Bubuk } \\
\text { (Langsung) }\end{array}$ & $\begin{array}{l}\text { Lesitin } \\
\text { Cair } \\
\text { (Premiks) }\end{array}$ & $\begin{array}{l}\text { Lesitin Cair } \\
\text { (Langsung) }\end{array}$ \\
\hline 0 & $E$ & $\mathrm{E}$ & $E$ & $E$ \\
\hline 0,5 & $\mathrm{E}$ & $\mathrm{E}$ & $\mathrm{E}$ & D \\
\hline 1,0 & & & $\mathrm{E}$ & D \\
\hline 2,0 & D & $E$ & & $\mathrm{E}$ \\
\hline 2,5 & & & & $E$ \\
\hline 3,0 & & & & $\mathrm{E}$ \\
\hline 4,0 & $E$ & $E$ & & \\
\hline
\end{tabular}

Keterangan: Kriteria SDP; $A$ = sangat baik; $B$ = baik; $C=$ sedang; $D=$ dapat diterima; $\mathrm{E}$ = tidakdapat diterima. Untukbagian tabel yang kosong, data tidak tersedia karena tidak dilakukan pengujian pada jumlah sediaan tersebut

\section{Insolubility index}

Penambahan lesitin bubuk hingga jumlah sediaan 2,0\% tidak berpengaruh pada insolubility index. Pada jumlah sediaan $4,0 \%$ dengan metode langsung dapat mengurangi insolubility index. Lesitin cair pada jumlah sediaan $0,5 \%$ signifikan dapat menurunkan insolubility index khususnya pada metode premiks (Dunnet, $P<0,05$ ). Seiring dengan peningkatan jumlah sediaan efek penurunan tidak signifikan dan fluktuatif seperti yang ditampilkan pada Gambar 4.

Lesitin kedelai dapat membentuk jaringan dengan protein dan protein menyelimuti partikel cokelat untuk mencegah sedimentasi (Selamat et al., 1998), namun interaksi yang terlalu kuat seiring bertambahnya dosis yang juga memengaruhi kondisi ionik dapat menghasilkan agregat. Berdasarkan Wang et al., 2017, zeta-potential (besaran gaya elektrostatis/muatan tolak menolak-tarik menarik an- tar partikel) pada emulsi isolate protein whey semakin negatif dari $(-43,0 \mathrm{mV}$ ke $-48,1 \mathrm{mV})$ pada penambahan lesitin hingga $0,75 \%$ yang mencegah agregat, namun pada penambahan jumlah sediaan di atas $0,75 \%$ hingga $2,00 \%$ terjadi sedikit peningkatan dari $-48,1 \mathrm{mV}$ ke $-45,9 \mathrm{mV}$. Secara umum boleh dikatakan tidak ada keterkaitan korelasi langsung antara wettability dengan insolubility index yang mencerminkan tingkat kelarutan produk.

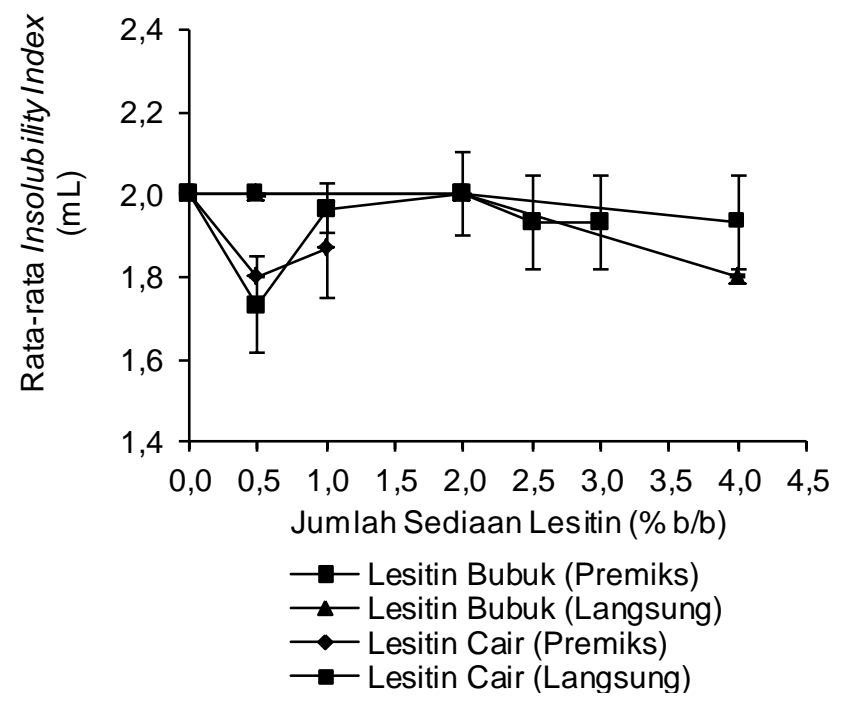

Gambar 4. Insolubility index minuman serbuk cokelat menggunakan lesitin bubuk dan lesitin cair

\section{Wettability minuman serbuk cokelat mengguna- kan lesitin \\ Berdasarkan Gambar 5, baik lesitin bubuk mau-} pun cair dapat meningkatkan wettability dengan intensitas yang berbeda. Peningkatan wettability mengikuti pola logaritmik terhadap peningkatan jumlah sediaan lesitin dimana pada jumlah sediaan rendah peningkatannya tinggi namun sampai pada jumlah sediaan tertentu $(2,0 \%$ untuk lesitin bubuk dan lesitin cair), maka penambahan jumlah sediaan tidak meningkatkan wettability secara signifikan. Hal ini sejalan dengan hasil penelitian Vissotto et al. (2006) yang menemukan pola yang serupa namun dengan dosis optimum lesitin pada $0,5 \%$.

Lesitin bubuk hingga jumlah sediaan $4,0 \%$ baik dengan perlakuan premiks maupun langsung masih belum dapat memenuhi target wettability maksimum 30 detik. Lesitin cair lebih efektif meningkatkan wettability pada jumlah sediaan yang sama dengan biaya lebih rendah (harga lesitin cair Rp. 51.330,-/kg dan lesitin bubuk Rp. 140.416,-/kg). Hal ini sedikit bertolak belakang dengan fakta bahwa kandungan bahan aktif fosfolipid pada lesitin bubuk (minimum $30 \%$ ) tiga kali lebih banyak dibanding lesitin cair (minimum 97\%). Fosfolipida pada lesitin merupakan komponen amfifilik dimana bagian ujung kepala fos- 
fat bersifat hidrofilik dan bagian ekor asam lemak yang bersifat hidrofobik sehingga lesitin merupakan surfaktan dan pengemulsi alami yang baik (Kralova dan Sjoblom, 2009). Semakin luas cakupan area partikel yang dilapisi oleh lesitin akan memberikan sudut kontak yang kecil pada permukaan antara partikel dan air yang sangat membantu pada proses pembasahan (Ji et al., 2017). Pada lesitin bubuk tidak menyelimuti permukaan partikel produk namun posisinya hanya bersinggungan sehingga luas area kontak lebih kecil dibanding pada lesitin cair. Hal ini menjelaskan hasil wettability yang lebih baik pada lesitin cair.

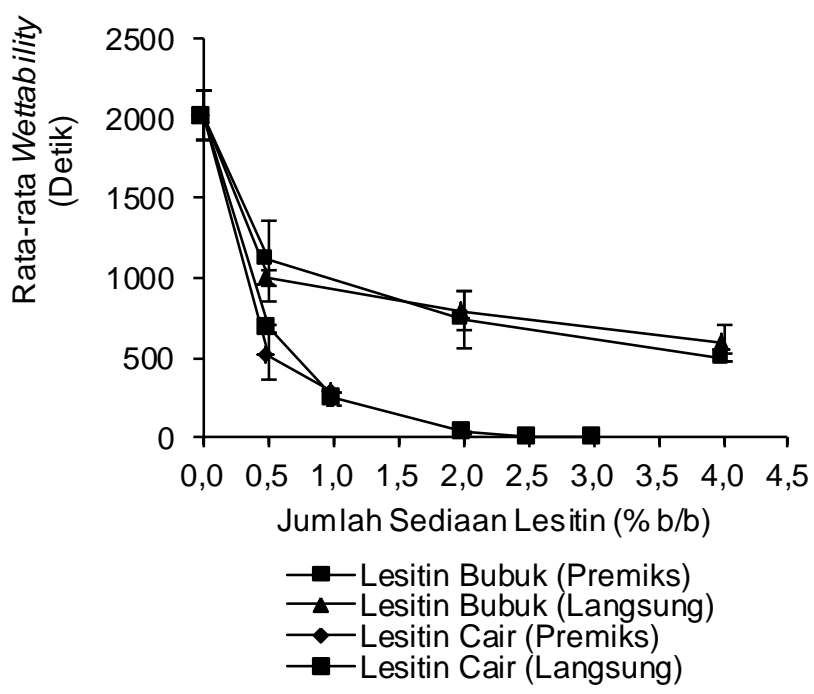

Gambar 5. Wettability minuman serbuk cokelat menggunakan lesitin bubuk dan lesitin cair

Tidak ada perbedaan signifikan hasil wettability antara perlakuan penambahan lesitin metode langsung dengan premiks baik pada lesitin bubuk maupun cair pada jumlah sediaan yang sama. Pada lesitin cair jumlah sediaan 2,5 dan $3,0 \%$ hasil wettability sesuai target di bawah 30 detik (6 dan 3 detik). Berdasarkan hasil tersebut, maka lesitin cair jumlah sediaan $2,5 \%$ dengan metode perlakuan penambahan langsung dipilih untuk meningkatkan wettability pada formula terpilih P21.

Berdasarkan hasil uji tetrad untuk menguji perbedaan antar sampel, hanya 5 dari 20 respon panelis yang dapat menjawab dengan benar sedangkan batas dimana dikatakan signifikan adalah 11 dari 20 respon (95\% level kepercayaan). Tidak ada perbedaan nyata antara sampel minuman serbuk cokelat P21 dengan dan tanpa penambahan lesitin cair $2,5 \%$ dalam hal sensori. Hal ini sesuai dengan hasil penelitian Selamat et al. (1998), dimana penambahan lesitin kedelai hingga 4,0\% (dengan 20\% bubuk cokelat teralkalisasi) tidak memengaruhi rasa secara signifikan karena rasa langu kedelai tidak terdeteksi.

\section{KESIMPULAN}

Formulasi minuman serbuk cokelat yang disukai oleh konsumen adalah dengan komposisi susu bubuk lemak utuh instan $40 \%$, gula kastor $40 \%$, bubuk cokelat $10 \%$, garam $0,3 \%$ dan maltodekstrin mengisi hingga 100\%. Untuk meningkatkan wettability formula produk tersebut, lesitin cair lebih efektif dibandingkan lesitin bubuk. Terdapat keterbatasan pada lesitin cair dengan jumlah sediaan tinggi yang membuatnya menjadi lengket. Perlakuan penambahan lesitin dengan metode premiks tidak memberikan hasil yang berbeda signifikan pada wettability dibandingkan dengan metode langsung. Metode premiks kurang efisien dari sisi operasional karena diperlukan dua tahap pencampuran. Jumlah sediaan lesitin cair yang mampu mencapai target wettability di bawah 30 detik adalah 2,5\% (b/b) dengan hasil 6 detik. Efek dari penambahan lesitin cair ini adalah hilangnya partikel terapung, meningkatnya ukuran partikel yang juga memengaruhi densitas kamba menjadi lebih rendah. Penambahan lesitin cair 2,5\% tidak memberikan perbedaan yang signifikan dari segi sensori (rasa).

\section{UCAPAN TERIMA KASIH}

Ucapan terima kasih disampaikan kepada PT Frisian Flag Indonesia atas kesempatan dan dukungan yang diberikan untuk penelitian ini.

\section{DAFTAR PUSAKA}

Abdelaziz IB, Sahli A, Bornaz A, Scher S, Gaiani C. 2014. Dynamic method to characterize rehydration of powdered cocoa beverage: Influence of sugar nature, quantity and size. Powder Technol 264: 184-189. DOI: 10.1016/j.powtec.2014. 05.031 .

Ackbarali DS, Maharaj R. 2014. Sensory evaluation as a tool in determining acceptability of innovative products developed by undergraduate students in food science and technology at the University of Trinidad and Tobago. J Curriculum Teaching 3: 10-27. DOI: 10.5430/jct. Bn1p10.

Aliakbarian B, Casaza AA, Nani A, Perego P. 2017. Production of chocolate powdered beverage with enhanced instant properties. Chem Engineer Trans 57: 877. DOI: 10.3303/CET17571 47.

Bylund G. 1995. Dairy Processing Handbook. 392. Tetra Pak, Lund, Sweeden. 
Dhanalakshmi K, Ghosal S, Bhattacharya S. 2011. Agglomeration of food powder and applications. Crit Rev Food Sci 51: 432-441. DOI: 10.1080/ 10408391003646270.

Dogan M, Aslan D, Aktar T, Sarac MG. 2016. A methodology to evaluate the sensory properties of instant hot chocolate beverage with different fat contents: multi-criteria decision-making techniques approach. Eur Food Res Technol 242: 953-966. DOI: 10.1007/s00217-015-2602-z.

Dupas J, Forny L, Ramaioli M. 2015. Powder wettability at a static air-water interface. J Colloid Interf Sci 448: 51-56. DOI: 10.1016/j.jcis.2015. 01.086 .

Eduardo MF, Mello KGPC, Polakiewicz B, Lannes SCDS. 2014. Evaluation of chocolate milk beverage formulated with modified chitosan. J Agr Sci Tech 16: 1301-1312.

Ennis JM, Jesionka V. 2011. The power of sensory discrimination methods revisited. J Sens Stud 26: 371-382. DOI: 10.1111/j.1745-459X.2011.0 0353.x.

Fang Y, Selomulya C, Chen XD. 2008. On measurement of food powder reconstitution properties. Dry Technol 26: 3-14. DOI: 10.1080/073739307 01780928.

Fitzpatrick JJ, Lauwe Av, Coursol M, O'Brien A, Fitzpatrick KL, Ji J, Miao S. 2016. Investigation of the rehydration behaviour of food powders by comparing the behaviour of twelve powders with different properties. Powder Technol 297: 340-348. DOI: 10.1016/j.powtec.2016.04.036.

Fitzpatrick JJ, Salmon J, Ji J, Miao S. 2017. Characterisation of the wetting behaviour of poor wetting food powders and the influence of temperature and film formation. KONA Powder Part $J$ 34: 282-289. DOI: 10.14356/kona.2017019.

Forny L, Palzer S, Marabi A. 2011. Wetting, disintegration and dissolution of agglomerated water soluble powders. Powder Technol 206: 72-78. DOI: 10.1016/j.powtec.2010.07.022.

[IDF] International Dairy Federation 2005a. Dried Milk and Dried Milk Products-Determination of Insolubility Index. IDF 129 Brussels, Belgium.

[IDF] International Dairy Federation 2005b. Dried Milk and Dried Milk Products-Determination of Bulk Density. IDF 134 Brussels, Belgium.

[IDF] International Dairy Federation 2013. Instant Dried Milk-Determination of The Dispersibility and Wettability. IDF 087 Brussels, Belgium. ljabadeniyi OA, Pillay Y. 2017. Microbial safety of low water activity foods: study of simulated and durban household samples. J Food Quality 2017: 1-7. DOI: 10.1155/2017/4931521.

Ji J, Cronin K, Fitzpatrick J, Miao S. 2017. Enhanced wetting behaviours of whey protein iso-late powder: The different effects of lecithin addition by fluidised bed agglomeration and coating processes. Food Hydrocolloid 71: 94-101. DOI: 10.1016/j.foodhyd.2017.05.005.

Kent RM, Fitzgerald GF, Hill C, Stanton C, Ross RP. 2015. Novel approaches to improve the intrinsic microbiological safety of powdered infant milk formula. Nutrients 7: 1217-1244. DOI: 10.3390/ nu7021217.

Kralova I, Sjöblom J. 2009. Surfactants used in food industry - a review. J Disper Sci Technol 30: 13 63-1383. DOI: 10.1080/01932690902735561.

Lallbeeharry $\mathrm{P}$, Tian Y, Fu N, Wu WD, Woo MW, Selomulya, Chen XD. 2014. Effects of ionic and nonionic surfactants on milk shell wettability during co-spray-drying of whole milk particles. J Dairy Sci 97: 5303-5314. DOI: 10.3168/jds. 2013-7772.

Naik B, Kumar V. 2014. Cocoa butter and its alternatives - a review. J Bioresource Eng Technol 2: 1-11.

Paixao JA, Rodrigues JB, Esmerino EA, Cruz AG, Bolini HMA. 2014. Influence of temperature and fat content on ideal sucrose concentration, sweetening power, and sweetness equivalence of different sweeteners in chocolate milk beverage. J Dairy Sci 97: 7344-7353. DOI: 10.3168/ jds.2014-7995.

Pichot R, Watson RL, Norton IT. 2013. Phospholipids at the interface: current trends and challenges. Int J Mol Sci 14: 11767-11794. DOI: 10.3390/ijms140611767.

Richard B, Page JFL, Schuck P, Andre C, Jeantet R, Delaplace G. 2013. Towards a better control of dairy powder rehydration processes. Int Dairy $\mathrm{J}$ 31: 18-28. DOI: 10.1016/j.idairyj.2012.07.007.

Selamat J, Hussin N, Zain AM, Che Man YB. 1998. Effects of alkalized cocoa powder and soy lecithin on physical characteristics of chocolate beverage powders. J Food Process Pres 22: 241254. DOI: 10.1111/j.1745-4549.1998.tb00348.x.

Selomulya C, Fang Y. 2013. 15-Food Powder Rehydration. Handbook of Food Powders. 379-408. Woodhead Publishing Series in Food Science, Technology and Nutrition. DOI: 10.1533/978085 7098672.2.379. 
Tian Y, Fu Nan, Wu WD, Zhu D, Huang J, Yun S, Chen XD. 2014. Effects of co-spray drying of surfactants with high solids milk on milk powder wettability. Food Bioprocess Tech 7: 31213135. DOI: 10.1007/s11947-014-1323-9.

Vissotto FZ, Montenegro FM, Santos ACVSM, Rastogi SA. 2006. Evaluation of the influence of lecithination and agglomeration on the physical properties of cocoa powder beverage (cocoa beverage powder lecithination and agglomeration). Ciênc Tecnol Aliment 26: 666-671. DOI: 10.1590/S0101-20612006000300028.
Vissotto FZ, Jorge LC, Makita GT, Rodrigues MI, Menegali FC. 2010. Influence of the process parameters and sugar granulometry on cocoa beverage powder steam agglomeration. J Food Eng 97: 283-291. DOI: 10.1016/j.jfoodeng.200 9.10.013.

Wang S, Shi Y, Tu Z, Zhang L, Wang H, Tian M, Zhang N. 2017. Influence of soy lecithin concentration on the physical properties of whey protein isolate-stabilized emulsion and microcapsule formation. J Food Eng 207: 73-80. DOI: 10.1016/j.jfoodeng.2017.03.020. 